\title{
Mycorrhizal fungi and biological activity of humus layer in polluted pine forests in the surroundings of Oulu
}

\author{
ANNA MARI MARKKOLA and RAUNI OHTONEN
}

\begin{abstract}
MARKKOLA, A.M. \& OHTONEN, R. 1988: Mycorrhizal fungi and biological activity of humus layer in polluted pine forests in the surroundings of Oulu. - Karstenia 28:45-47.

The condition and types of ectomycorrhizae of Scots pine Pinus sylvestris and the biological activity of soil micro-organisms in the humus layer of polluted pine forests were studied in the surroundings of Oulu, northern Finland. Biological activity, expressed as the rate of humus respiration and as dehydrogenase enzyme activity, decreased towards the central, most polluted area with higher sulphur and nitrogen contents in the humus layer. The ectomycorrhizae of Scots pine were less ramified and poorly developed in the central area. The number of mycorrhizal types and the number of mycorrhizal species encountered in the sporophore inventories were lower in the two most polluted zones than in the cleaner sites. The type composition of the mycorrhizae was altered in the polluted sites.
\end{abstract}

Anna Mari Markkola \& Rauni Ohtonen, Department of Botany, University of Oulu, Linnanmaa, SF-90570 Oulu, Finland

\section{Introduction}

Rather little is known about the biological processes in forest soil affected by air-borne pollutants. The biology of the humus layer has been studied since 1987 in polluted pine forests in the Oulu region. The project includes studies on ectomycorrhizal symbiosis, on the amount and activity of soil micro-organisms and on some chemical parameters of the humus layer. It is part of the Finnish Research Project on Acidification supported by the Ministry of the Environment. Some preliminary results of the first year of the study are briefly reported here. Further field and laboratory work, including nutrient analyses, will be done in 1988 and the data from both years will then be analysed in detail.

\section{Study area}

The Oulu region is polluted mainly by the pulp and chemical industry. The annual amounts of the most important emissions have been estimated at: $\mathrm{SO}_{2}$ 10-12000, $\mathrm{NO}_{\mathrm{x}} 7-8000$, dust 7-8 $000, \mathrm{H}_{2} \mathrm{~S}$
$1200, \mathrm{~Pb} 20$ and $\mathrm{Hg} 0.2$ tn (Vuononvirta et al. 1984).

The study sites were chosen in dry-dryish pine stands in different pollution zones (five sites per zone) determined by reference to the sulphur content of the pine needles. The sulphur contents are as follows - zone I: sulphur content not determined; zone II: S < 1100 ppm, zone III: S 1 100-1 300 ppm; zone IV: S > $1300 \mathrm{ppm}$ (Karhu 1986). The study sites in zone I are located about $20 \mathrm{~km}$ from the emission sources and the central sites in the zone IV at a distance of 1-6 km from the sources (Markkola \& Ohtonen 1987).

\section{Material and methods}

Samples were collected monthly during the 1987 growing season, from early June till mid October, mycorrhizal samples only in September (7.14.IX.1987). Humus cores were taken at random with a 3-cm-wide soil borer. Mycorrhizal counts were made under a dissection microscope on each of the five soil cores separately. Different types of ecto- 
mycorrhizae in Scots pine roots were characterized and their proportions counted. The condition of the mycorrhizae was estimated roughly, mainly according to the mantle appearance (Lehto 1984). For other analyses several cores were mixed (15-35 depending on the depth of the humus layer). Soil respiration was measured by the static chamber method (de Jong et al. 1979) and dehydrogenase activity by the TTC method (Malinen 1983), both on the mixed humus sample. The total nitrogen content of the humus was determined by a micro-Kjeldahl method (Kubin 1978 ) and the total sulphur content by X-ray analysis (Huttunen et al. 1985). The sporophores of mycorrhizal fungi growing in the study sites were inventoried in September (7.-14.IX.1987).

\section{Results and discussion}

In the two central, more polluted zones III and IV, the total sulphur and nitrogen contents of the humus were distinctly higher than in the background and suburban areas (zones I and II), total $\mathrm{N}$ being highest $(1.12 \% \mathrm{DW})$ in zone III. $\mathrm{pH}$ was slightly higher in zones III and IV and the depth of the humus layer increased towards the centre (Table 1). The increase in $\mathrm{pH}$ may be due to the alkaline components of the deposition. Biological activity, expressed as the rate of humus respiration and as dehydrogenase enzyme activity, was lower in the two central zones III and IV than in the outer sites (zones I and II) (Table 1). Being part of the biological activity, litter decomposition could be reduced by the deposition of air pollutants (Berg 1986). This could also partly explain the deeper humus observed in the central city area, though in these sites the deposition has probably also increased the biomass and litter production of the field layer.
At the root level, deleterious effects were clearly observed in the most polluted area, zone IV, where the ectomycorrhizae of Scots pine were poorer and the roots less ramified than in the other zones. The proportion of well-developed mycorrhizae was $17.8 \%$ in zone IV, whereas in the rest of the study area the proportion varied between 25.7 and $29.8 \%$. In zone III, however, the root ramification value was higher than in all the other zones (6.8 root tips $/ \mathrm{cm}$ root length) and on an average the ectomycorrhizae were as well developed as in the less polluted zones I and II (Table 2). Damaged root tips were observed more often in zones III and IV than in zones I or II.

The number of mycorrhizal types was lower in zones III and IV ( 6 and 9 , respectively) than in zones I and II (12 and 14, resp.). The number of mycorrhizal species encountered in the sporophore inventories was also lower in zones III and IV (Table 2). Rhizomorphous types of mycorrhizae (e.g. Piloderma croceum, Dermocybe) were rather rare in the city centre, whereas ectomycorrhizae formed by Cenococcum geophilum and a smooth Lactarius type were even more abundant in the central area than in zones I and II.

The effects of air pollution on mycorrhizae and their role in forest decline are nowadays widely discussed (Meyer 1984, Gulden \& Høiland 1985). Reduction in the number and biomass of mycorrhizal roots and damage to mycorrhizae have been observed in declining coniferous forests (Blaschke 1986, Meyer 1987). Even more drastic changes, the decline or disappearance of some mycorrhizal fungi, have been found in sporophore inventories, e.g. in the Netherlands (Arnolds 1985).

The observations on the mycorrhizae and the decreased biological activity of humus in the polluted pine forests in Oulu cannot be explained solely by the sulphur deposition. In the Central European forests

Table 1. Some properties and the biological activity of the humus layer in the study zones. The values are the means of five samples collected monthly (1.VI.-19.IX.1987).

\begin{tabular}{lcccc}
\hline Zones & I & II & III & IV \\
\hline Depth of humus $(\mathrm{cm})$ & 3.8 & 4.4 & 6.6 & 7.1 \\
pH & 3.93 & 3.94 & 4.03 & 4.02 \\
Total sulphur $(\mu \mathrm{g} / \mathrm{g} \mathrm{DW})$ & 1570 & 1890 & 2370 & 2410 \\
Total nitrogen $(\% \mathrm{DW})$ & 0.82 & 0.89 & 1.12 & 1.02 \\
Soil respiration $(\mu \mathrm{g} \mathrm{CO} / \mathrm{g} / \mathrm{h})$ & 49.3 & 43.6 & 31.3 & 30.3 \\
Dehydrogenase act. $(\mu \mathrm{mol} \mathrm{TPF} / \mathrm{g} / 24 \mathrm{~h})$ & 1.44 & 1.28 & 1.11 & 1.20 \\
\hline
\end{tabular}


Table 2. Condition of Scots pine ectomycorrhizae and the numbers of mycorrhizal types and ectomycorrhizal species producing sporophores in the study zones. The values are the means of five replicate samples collected on 7.-14.IX.1987, when the sporophore inventories were also made.

\begin{tabular}{lcccc}
\hline Zones & I & II & III & IV \\
\hline Proportion of well-developed mycorrhizae (\%) & 29.8 & 25.7 & 29.0 & 17.8 \\
Ramification (root tips/cm root length) & 6.6 & 6.4 & 6.8 & 5.3 \\
Number of mycorrhizal types & 12 & 14 & 6 & 9 \\
Number of mycorrhizal species producing sporophores & 16 & 14 & 7 & 6 \\
\hline
\end{tabular}

heavy $\mathrm{N}$ deposition has been suggested to be one of the main factors in mycorrhizal declines (Meyer 1987). In Finland nitrogen fertilization of forests has weakened the mantle development in ectomycorrhizae (Laiho et al. 1987), but in this study no such observations were made regarding the effect of nitrogen, at least not in the macroscopic examination. In zone III, which had the highest $\mathrm{N}$ content, the condition of the mycorrhizae was as good as in the cleaner zones. The reduction in the number of mycorrhiza types and in the abundance of some types could, however, be partially due to nitrogen deposition. In northern Finland nitrogen fertilization of pine forests has altered the species composition of the ectomycorrhizal fungi (Ohenoja 1988). Some nitrogen fertilizers have also been observed to reduce the biological activity of the forest soil (Ohtonen, unpubl.).

In addition, consideration should be given to the probable nutrient imbalance in the soils with the highest sulphur and nitrogen deposition and to the accumulation of lead and other heavy metals in polluted urban humus. Analyses of heavy metals in the humus and examination of all the results relating to a particular site in this study will probably throw more light on these matters.

\section{References}

Arnolds, E. (ed.) 1985: Veranderingen in de paddenstoelenflora (mycoflora). - Weten. meded. Konin. Neder. Natuurhist. Ver. 167:1-101.

Berg, B. 1986: The influence of experimental acidification on nutrient release and decomposition rates of needle and root litter in the forest floor. - Forest Ecol. Man. 15:195213.

Blaschke, H. 1986: Einfluss von saurer Beregnung und Kalkung auf die Biomasse und Mykorrhizierung der Feinwurzeln von Fichten. - Forstw. Cbl. 105:324-329.
DeJong, E., Redmann, R.E. \& Ripley, E.A. 1979: A comparison of methods to measure soil respiration. Soil Sci. 127:300-306.

Gulden, G. \& Høiland, K. 1985: The role of ectomycorrhiza in a situation of air pollution and forest death. Agarica 12:341-357.

Huttunen, S., Laine, K. \& Torvela, H. 1985: Seasonal sulphur contents of pine needles as indices of air pollution. - Ann. Bot. Fennici 22:343-359.

Karhu, M. 1986: Männyn neulaset ja koivun lehdet ilman rikkikuormituksen ilmentäjinä. - $72 \mathrm{pp}$. Unpubl. licenciate thesis, Bot. Inst. Univ. Oulu.

Kubin, E. 1978: Kasvimateriaalin typpipitoisuuden määrittämisestä. (Abstract: The determination of the organic nitrogen in plant material). - Oulun yliopiston kasvitieteen laitoksen monisteita $7: 1-21$.

Laiho, O., Sarjala, T., Hyvärinen, R. \& Rautiainen, L. 1987: Lannoituksen vaikutus männikön mykoritsoihin. - Folia For. 699:1-22.

Lehto, T. 1984: Kalkituksen vaikutus männyn mykoritsoihin. - Folia For. 609:1-16.

Malinen, P. 1983: Dehydrogenaasiaktiivisuuden määrittäminen humuksesta. Mikrobien kokonaisaktiivisuuden mittaus. - Oulun yliopiston kasvitieteen laitos. $13 \mathrm{~s}$. Oulu.

Markkola, A.M. \& Ohtonen, R. 1987: The effect of acid deposition on fungi in forest humus. - Ectomycorrhiza and acid rain. Proceedings of the Workshop on Ectomycorrhiza/Expert Meeting. Dec. 10.-11. 1987. Berg en Dal, the Netherlands: $122-126$.

Meyer, F.H. 1984: Mykologische Beobachtungen zum Baumsterben. - Allg. Forstz. 39:212-228.

Meyer, F.H. 1987: Ectomycorrhiza and decline of trees. Ectomycorrhiza and acid rain. Proceedings of the Workshop on Ectomycorrhiza/Expert Meeting. Dec. 10.-11. 1987. Berg en Dal, the Netherlands: 9-31.

Ohenoja, E. 1988: Behavior of mycorrhizal fungi in fertilized forest. - Karstenia 28:27-30.

Vuonovirta, P., Laitinen, L. \& Mikkonen, K. 1984: Ilman laatu Oulussa vuosina 1979-1983. - Ympäristö ja Terveys 15:156-161.

Accepted for publication

on 10 June 1988 